\title{
Missed Opportunities, Good InTEntions: The Takings Decisions of Justice Antonin Scalia
}

\author{
Richard A. Epstein* \\ University of Chicago
}

\begin{abstract}
The late Justice Antonin Scalia sensibly pushed his powerful originalist agenda as a bulwark against activist justices of any persuasion from enacting their policy preferences into law. But while this commitment to originalism may explain what the justices should not do, it does not explain, affirmatively, how they should interpret constitutional texts in accordance with the originalist agenda. One area in which this is most critical is the law of takings, which polices the boundary line between private rights and public power. Here it is necessary to integrate explicit constitutional provisions dealing with the terms "taken," "private property," "just compensation," "public use," and the implied "police power" into a coherent whole. The law of takings is relatively straightforward when the government takes private property into public possession. But it is far more difficult to explicate when private parties retain some interests in property after the government either occupies or regulates the use and disposition of the rest. Justice Scalia's application of takings law to such cases of divided interests has fallen short in four key contexts: the permitting process in Nollan; rent control in Pennell; development rights in Lucas; and environmental protection schemes in Stop the Beach Renourishment. In these cases, Justice Scalia often reached the right result for the wrong reasons, often on ad hoc grounds. The correct analysis requires a far more thoroughgoing protection of private property interest in the context of both regulatory and possessory takings. This article explains how he should have handled these missed opportunities.
\end{abstract}

\section{CONTENTS}

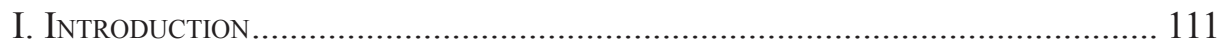

II. Nollan v. California Coastal Commission.............................................. 115

III. Pennell v. City of San Jose. ............................................................. 119

IV. Lucas v. South Carolina Coastal Council ........................................... 123

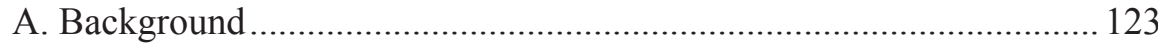

B. The Prima Facie Taking ............................................................... 124

* Laurence A. Tisch Professor of Law, New York University School of Law; The Peter and Kirsten Bedford Senior Fellow, The Hoover Institution; The James Parker Hall Distinguished Professor of Law Emeritus and Senior Lecturer, The University of Chicago. My thanks to Philip Cooper and Julia Haines, University of Chicago Law School, Class of 2017 for their usual excellent and prompt research assistance. 


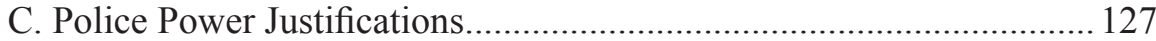

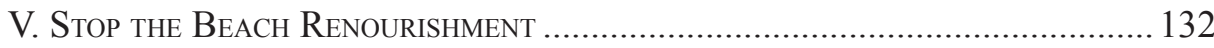

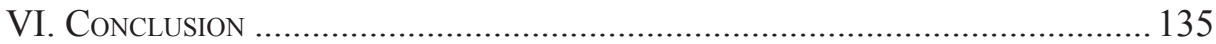




\section{INTRODUCTION}

In many ways the most distinctive contribution of the late Justice Antonin Scalia was his devotion to the originalist approach to constitutional interpretation, which, roughly speaking, requires the justices to seek out the best public understandings of particular positions and terms as understood at the time of the Constitution's adoption. His enduring influence in this regard will lie in his powerful attack on advocates of the living Constitution, who on many occasions find it difficult to distinguish between their own policy preferences and the legal rules that can be fairly extracted from the constitutional text in light of its structure and historical context. ${ }^{1}$ To the extent that originalism - all too often a term of art-embraces all three elements of text, history and structure, in my view it is surely right. The dangers to the rule of law, to the separation of powers, and to the legitimacy of the Supreme Court are too great if that Court is thought to be a political body governed largely, if not exclusively, by the policy goals of the people who dictate the relevant legal doctrines and frameworks. As a former administrative law professor, Scalia was far more comfortable talking about how constitutional interpretation intersects with the structural features of the Constitution. For example, his famous 1988 Taft lecture, appropriately enough, spoke quite persuasively about Taft's powerful and still-influential opinion in Myers $v$. United States, ${ }^{2}$ which considered the open question of the president's removal power in light of the Constitution's separationof-powers framework. No system of interpretation is ever error free, but Justice Scalia was surely right to insist that such errors are less frequent and less severe than those that emerge from interpretative systems that allow unmoored philosophical speculation to determine constitutional structures. ${ }^{3}$

In this regard, I think that Justice Scalia's impassioned dissent in Obergefell v. $H_{o d g e s}{ }^{4}$ captures the right mood on this issue. There is little question regarding the historical consensus that the regulation of marriage and sexuality was a matter for legislative discussion, so that the decision in Obergefell completed a constitutional conversion to a new set of political beliefs - one which I in general share - with no foundation in the text, history or structure of the Constitution. ${ }^{5}$ Yet there is an uneasy dissonance in the Obergefell dissent insofar as it can be read to imply that the freedom of the People "to govern themselves" through the legislative process is subject to no substantive constitutional limitations at all. ${ }^{6}$

That position cannot be tenable unless the entire structure of the Bill of Rights and Reconstruction Amendments are consigned to the shadows of American constitutional law, governed perhaps only by the weak rational basis test that is frequently used to uphold state regulation of private property. ${ }^{7}$ The key weaknesses

For my defense of this position, see Richard A. Epstein, The Classical Liberal ConstiTUTION, ch. 3 (2014).

272 U.S. 52 (1926).

Antonin Scalia, Originalism: The Lesser Evil, 57 U. CIN. L. Rev. 849 (1988-1989).

135 S. Ct. 2584, 2626 (2015).

To see the development of the current law, trace the progression from Bowers v. Hardwick, 478 U.S. 186 (1986) through Lawrence v. Texas, 539 U.S. 558 (2003).

Obergefell, 135 S. Ct. at 2627 (Scalia, J. dissenting).

Early consideration of this test can be found in James Bradley Thayer, The Origin and Scope of the American Doctrine of Judicial Review, 7 Harv. L. Rev. 129 (1893). 
of Scalia's broad claim in Obergefell are two. First, it does not tell us when constitutional protections override democratic processes. Second, it does not give rise to the proper set of interpretive techniques that should be used to reach the correct result on this balancing question. On these matters, general questions of ideological predisposition have to yield to concrete interpretive approaches, in which it is not sufficient to rely on any well-nigh-conclusive presumption that speaks about either the protection of individuals from democratic oppression or the necessity for extended and informed public deliberation over collective decisions.

Working out the correct balance between legislative decisions and individual rights in the context of the Takings Clause requires close attention to each element of the overall picture. The clause is simplicity itself: "nor shall private property be taken for public use, without just compensation." "Every word counts, such that a thorough knowledge of private law allows a justice to identify and rely on a long and continuous set of understandings about its four constituent terms"private property," "taken," "public use," and "just compensation." Matters of constitutional history and structure also point to the critical role of an unstated topic, namely the police power. ${ }^{9}$ That protean term is not some new-found living constitutional contrivance intended to undermine the public meaning of the Takings Clause or to upend our basic constitutional order. It has been a long-time staple of American constitutional law - one that long predates the arrival of the living Constitution $^{10}$ - in which it acts, within a general classical liberal framework, as an all-purpose corrective to the proper limitations on individual and corporate rights, whether they are protected through the Takings Clause or any other provision of the Constitution. ${ }^{11}$

To a hardline textualist, the introduction of any implied term into the Constitution, or for that matter into any statute or contract, becomes the source of genuine uneasiness. But to anyone who has worked with the historical evolution of either Roman or early English law, dealing with these unstated terms, often as a matter of necessary implication, is all in a day's work. No form of interpretation can do without these devices, and none should try. Indeed, the police power framework is just one of many implicit add-ons that inform constitutional interpretation. Justice Scalia wisely imported the entire doctrine of unconstitutional conditions into the Takings Clause in Nollan v. California Coastal Commission. ${ }^{12}$ The Court has also applied principles of necessary implication to address intergovernmental

\section{U.S. Const. amend. V.}

$9 \quad$ See Lochner v. New York, 198 U.S. 45, 53 (1905): "The right to purchase or to sell labor is part of the liberty protected by [the Fourteenth] amendment, unless there are circumstances which exclude the right. There are, however, certain powers, existing in the sovereignty of each State in the Union, somewhat vaguely termed police powers, the exact description and limitation of which have not been attempted by the courts. Those powers, broadly stated and without, at present, any attempt at a more specific limitation, relate to the safety, health, morals and general welfare of the public."

10 See Thomas Cooley, Treatise on the Constitutional Limitations which Rest Upon the Legislative Powers of the States of the American Union (1868); Christopher G. Tiedeman, A Treatise on the Limitations of the Police Power of the United States (1886); Ernst Freund, The Police Power, Public Policy and Constitutional Rights (1904).

11 Alan Jones, Thomas M. Cooley and "Laissez-Faire Constitutionalism": A Reconsideration, 53 J. Ам. Hist. 751, 755 (Mar. 1967) (noting the Jeffersonian strand in his thought in which the police power was a means to limit the concentrated corporate power).

12483 U.S. 825 (1987). 
immunities. ${ }^{13}$ One can also point to the Court's approach to questions of immunity from taxation as between state and federal governments, ${ }^{14}$ of state immunity from federal government regulation of its own activities, ${ }^{15}$ and of how the Congress and the President should divide control over foreign relations and diplomatic recognition. ${ }^{16}$ The issue is not whether we practice the fine and mysterious art of interpretation by implication. Rather, our only choice is whether to do that task poorly or well.

In order to deal with that question, it is critical, even for an originalist, to examine each disputed doctrine against the larger framework of the Constitution itself, which then asks the question of which view on any disputed question is consistent with its overall text, structure, and purpose. His originalist predilections made it difficult for Justice Scalia to understand that there is no necessary, or even implied, connection between originalism and judicial restraint. The simple observation here is that many constitutional provisions, including the Takings Clause, speak in sweeping terms. The phrase "private property," for example, covers not only land, chattels and animals, but also a variety of partial interests in land, including mortgages, leases, mineral rights, and future interests, all of which have to be worked into the system. To make matters still more difficult, all forms of intellectual property have to be integrated into the overall takings analysis, even though certain rights, like trade secrets, patents, copyrights and trademarks, are the results of elaborate compromises of conflicting interests. In light of these complications, an approach to constitutional interpretation that elevates judicial restraint over all other values may resist the proactive development of a coherent theory of property rights that accounts for these nuances. Indeed, Justice Scalia and I once had a debate about the general question of judicial restraint before he went on the Supreme Court. In this discussion, Justice Scalia opted strongly for judicial restraint over general theoretical consistency. ${ }^{17} \mathrm{I}$ had argued that broad and ambiguous constitutional provisions should be read consonant with their general sweep and implications. In contrast, Justice Scalia, more the institutionalist and less the theorist, took less interest in the standard principles of constitutional interpretation that imitate those long-used in private law disputes under a jurisprudence that was very much a part of the common-law interpretive process employed during the founding era. As I have argued elsewhere, these implied exceptions to particular language are not based on changed social conditions, but are instead efforts to integrate indispensable and long-established concepts like necessity, self-defense, consent, assumption of risk, and the like into the interpretation of particular provisions. ${ }^{18}$ There is nothing

13 See Seminole Tribe of Florida v. Florida, 517 U.S. 44 (1996) (no suit against state by Indian tribe under Indian Gaming Regulatory Act, by a five-to-four vote); Alden v. Maine, 527 U.S. 706 (1999) (no suit under Fair Labor Standards Act against states in federal court, by a five-to-four decision).

14 McCulloch v. Maryland, 17 U.S. 316 (1819) (federal immunity from state taxation); Collector v. Day, 78 U.S. 113 (1870) (immunity of state employees from federal taxation), overruled by New York v. United States, 326 U.S. 572 (1946).

15 See Nat'l League of Cities v. Usery, 426 U.S. 833 (1976) (barring regulation of wages and hours of state employees under the Fair Labor Standards Act of 1974, 29 U.S.C. § 203), overruled by San Antonio Metropolitan Transit Auth. v. Garcia, 469 U.S. 528 (1985).

16 Zivotofsky v. Kerry, 135 S. Ct. 2076 (2015).

17 Cato Institute, Scalia v. Epstein: Two Views on Judicial Activism (1984).

18 For a more systematic account, see Richard A. Epstein, Linguistic Relativism and the Decline of the Rule of Law, 39 Harv. J. Law \& Pub. Pol. 583 (2016). 
particularly modern about these ideas, all of which were very much evident in the ancient Roman and English sources. And invoking modest common-law rules like nuisance is not an invitation to make massive leaps to policy conclusions, such as the notion that government intervention is necessary in competitive markets to redress the inequality of bargaining power between large firms and ordinary workers. ${ }^{19}$ The standard roster of implied terms is a powerful constraint on judicial adventurism that allows judges to avoid the greatest logical embarrassments associated with rigid textualism.

Justice Scalia contributed many important opinions on the constitutional protection of private property. In all of these, he focused his attention on the written text, paying less attention to larger questions of overall constitutional structure. This in turn resulted in him downplaying the key role of constitutional structure and the process of necessary implication. That somewhat-skewed focus undercut the coherence and generality of his opinions. To show how his thought process evolved, I shall look at four of his major decisions in chronological order. The first of these cases is Nollan v. California Coastal Commission ${ }^{20}$ in which Scalia's intuitions were reliable but his execution was flawed for one reason: he did not understand how various rules governing private monopoly behavior applied to the public permitting process in connection with the doctrine of unconstitutional conditions. A similar critique applies to Scalia's important concurrence in Pennell v. City of San Jose, ${ }^{21}$ which rightly takes issue with the lawyerly decision of Chief Justice Rehnquist, but glosses over the fundamental objections applicable to all rent control statutes. The same overall verdict should be rendered on his elaborate opinion in Lucas v. South Carolina Coastal Council, ${ }^{22}$ which suffers from two serious defects. The first is his futile effort to paper over the distinction between physical and regulatory takings by asserting that any government regulation that destroys all viable economic value is equivalent to a physical taking without explaining why the basic distinction is relevant or how it should be drawn. The second emerges from his uneasiness with the harm/benefit distinction that underlies the private law of nuisance and restitution. Finally, in Stop the Beach Renourishment, Inc. v. Florida Department of Environmental Protection, ${ }^{23}$ Scalia makes errors on both sides of the takings equation. On the one side, his misunderstanding of property rights in water law leads him to misstate the law of avulsion and thus to deny the powerful prima facie takings claim against the government. Next, on the other side of the case, his failure to take into account available forms of in-kind compensation leads him to underestimate the strength of the government's defense. In this case, the two errors canceled out so that the outcome of upholding the statutory scheme was correct. But in many situations, the in-kind compensation defenses are not available to the government, so that the

19 For discussion, see Richard A. Epstein, A Common Lawyer Looks at Constitutional Interpretation, 72 Bost. U. L. REv. 72 (1992).

20483 U.S. 825 (1987). For a more detailed account, see Richard A. Epstein, The Harms and Benefits of Nollan and Dolan, 15 N. ILl. U. L. REv. 479 (1995).

21485 U.S. 1, 15 (1988). For a more detailed account, see Richard A. Epstein, Rent Control and the Theory of Efficient Regulation, 54 BRook. L. REV. 741 (1988).

22505 U.S. 1003 (1992). For my earlier views, see Richard A. Epstein, Lucas v. South Carolina Coastal Council: A Tangled Web of Expectations, 45 STAN. L. REV. 1369 (1993).

23560 U.S. 702 (2010). For my more detailed commentary, see Richard A. Epstein, Littoral Rights Under the Takings Doctrine: The Clash Between the Ius Naturale and Stop the Beach Renourishment, 6 Duke J. Const. Law \& Pub. Pol. 38 (2011). 
Scalia approach can lead to massive underprotection of private property rights. It is no accident that three of these four cases involve beachfront property where rights in land and water come together. Those are often the hardest issues to resolve in private disputes. And because the public law of takings is parasitic on the private law, the failure to properly connect and resolve private law principles dooms the constitutional analysis. It is one thing to be any form of originalist or textualist. But no matter the degree of emphasis placed on these overlapping conceptions, it is the application of the overall system, not its general endorsement, that matters. In this case, the verdict is clear. Although Justice Scalia's instincts were often sound, his execution was just as often flawed. Those flaws have helped block the emergence of any consistent body of takings law. I now turn to these four cases.

\section{Nollan v. California Coastal Commission}

The most enduring contribution of Justice Scalia's opinion in Nollan ${ }^{24}$ is that it imported the well-established doctrine of unconstitutional conditions into the takings doctrine. ${ }^{25}$ The original Constitution had a twofold concern, seeking to set up the basic structures of government on the one side, and giving substantive protections to individuals against certain exercises of power on the other. The constant emphasis was on how private property and relations could be protected against government intrusion. From the beginning there was a soft underbelly to that structure, which was silent on the question of how the government should distribute various benefits to individuals. These benefits could come in the forms of direct grants of cash or property on the one hand, or in the granting of licenses and permits on the other. There is nothing about this issue that does not arise in connection with the admitted uses of government power, including the ability to license horses, cars and trucks on public roads.

Thus everyone knows that there is a deep difference between a regulation that says "if you wish to drive on Massachusetts roads, you have to agree to litigate any future divorce within the state," and a regulation that says "if you wish to drive on Massachusetts roads, you have to agree to litigate all disputes arising out of motor vehicle actions within the state in state courts." The first of these looks as though it is an effort to leverage control of power in a manner that would lead to impossible conflicts if replicated by other states. The second looks like an effort to reduce the frictions associated with resolving disputes over accidents. The former is best understood as an abuse of monopoly power, and the second as a proper application of that same power. Accordingly, the applicable branch of private law to explain these particular issues is in fact the antitrust (or competitions) law, which faces this question all the time in connection with tie-ins, exclusive dealing contracts, resale price maintenance and the like. ${ }^{26}$ The key to distinguishing proper use from abuse is

483 U.S. 825 (1987).

25 For my longish treatment of this issue, see Richard A. Epstein, Bargaining with the StATE (1993), covering the multiple permutations.

26 See, e.g., Jefferson Parish Hospital Dist. No. 2, v. Hyde, 466 U.S. 2 (1984) (tie-in cases). For discussion of efficiency trade-offs in this area, see Christian Ahlborn, David S. Evans 
to sort out efficient conditions from restrictive ones, knowing that these two stated cases are at polar extremes. There are always hard cases in the middle, but the initial task is to get the cases on the two extremes correct before trying to find the exact dividing point between them.

One reason why the problem was relatively quiescent for much of American constitutional law history is that both state and federal governments tended to operate within relatively narrow boundaries. The rise of government planning in the early twentieth century disrupted this trend, however, giving rise to restrictive mechanisms such as the building permit at issue in Nollan. This zoning movement is generally dated back to the Court's 1926 decision in Euclid v. Ambler Realty Company, ${ }^{27}$ which dismissed a constitutional challenge against a very aggressive system of land use restrictions that severely limited the development of the respondent's large 68 acre plot.

From the government point of view, one limitation of the zoning system is that it often makes it difficult to tailor the particular restriction to the governed location. This in turn presents two drawbacks. First, the state could miss the optimal configuration of development on any given plot of land, which from a social point of view can be regarded as a shortcoming of the system. Second, it can lose the opportunity to extract rents by taxing or partially expropriating the gains that the landowner would otherwise achieve by exercising his constitutional rights to own and develop real estate.

These issues are especially acute in sensitive real estate zones of great value, like the California coast. The permitting scheme at issue in Nollan had extraction of value written all over it. The Nollans owned a dilapidated beachfront house that they wished to rip down to construct a more spacious home similar to those built on countless beachfront lots across the nation. In this situation, there was no concern that the house in question would generate any harmful effects or intrude upon the rights of neighbors or the public at large. But the California Commission knew that the value of the building permit was enormous. For purposes of this exposition, set it at $\$ 1$ million, equal to the amount that the landowner would gain on net if the new house were completed as planned. At the same time, the Commission had a legitimate state objective to connect two separate public beaches with a path that went across the private land of all the landowners in between them. It therefore told all these owners that they could gain their permits only if they dedicated a public lateral easement over their property to the Commission for general public use. That easement would, to make matters simple, reduce the Nollans' property value by $\$ 100,000$. Absent any legal restriction on the Commission's ability to make this demand, the Nollans' choice was easy: by surrendering the easement in order to obtain a permit, they would increase the value of their property by $\$ 900,000$. But this forced choice is not so simple, for it is easily distinguishable from a hypothetical permit condition that demands new builders to install septic tanks so that they do not pollute neighboring properties or public waters. In the latter case, the end of preventing intrusion on the rights of others is clearly legitimate, and the only question is whether the permit in question is needed to deal with some real or imagined peril, which in all cases will always raise issues of whether the remedy is proportionate to the harm, given the risks of both over and under-enforcement.

\& A. Jorge Padilla, The Antitrust Economics of Tying: A Farewell to per se Illegality, 49 Antitrust Bulletin 287 (2004).

27272 U.S. 365 (1926). 
In an act of calculated defiance, the Nollans built their house without the permit and litigated the case to the bitter end. In the Supreme Court, Justice Scalia smelled a rat when it came to the Commission's actions, and consequently struck down the easement condition attached to the permit. He thus held that the lateral easement was a possessory interest in property and was therefore protected from an ordinary taking by a per se rule - take and you pay-just as if it had been an absolute fee simple interest. ${ }^{28}$ In so doing, he had to reject the forceful argument raised by Justice Brennan in dissent, who expressed uneasiness over a challenge to a permitting transaction which resulted in the landowner greatly improving the value of his property. ${ }^{29}$ Brennan took the position that if the Nollan buyout were not allowed, local governments would just refuse to issue building permits in the first place, leaving everyone worse off than before.$^{30}$ Therefore, the question is why reduce the level of discretion that local governments have in granting permits if they can retreat into their protective shells and create a tyranny of the status quo ante? In effect the Brennan approach was to invoke market arguments of mutual gain through trade to support the exaction practice.

To his lasting credit, Justice Scalia did not buy that argument. But the weakness of his general approach was apparent from the way in which he sought to deal with the fundamental challenge raised by the case. To Scalia, everything was a partial equilibrium analysis under existing law in which he was deeply reluctant to engage in any discussion based on first principles. The monopoly issues therefore never once made it explicitly into his analysis. Instead, he accepted the indefensible conceptual distinction between an outright taking of property on the one hand and a mere restriction of use on the other. By so doing, he made it clear that the framework that he developed would not apply to the various land use restrictions dealing with matters such as size, set back, and bulk of a new development. In line with earlier cases, he concluded that this takings analysis only applied to those actions that limited the landowner's right to exclude others, such as the lateral easement at issue in Nollan. ${ }^{31}$ He then insisted that "unless the permit condition serves the same governmental purpose as the development ban, the building restriction is not a valid regulation of land use but 'an out-and-out plan of extortion." "32 This passage offers no definition of what counts as "extortion," nor does it explain why the condition has to serve the same government purpose as some development ban. To Justice Scalia, this necessary connection between purpose and restriction could be established by showing that the limitation on redevelopment was intended to ensure that people driving along the Pacific Coast Highway, located to the landward side of the Nollans' plot, had an unobstructed view of the water. This framing leaves open the question of whether the Coastal Commission could rehabilitate its restriction by determining that such ocean views are so paramount as to justify limiting all new buildings to single-story structures.

It is therefore necessary to develop a more coherent account of why the Nollan decision was correct in the face of these objections and doctrinal loopholes. An understanding of the private law offers a way, indeed the only way, to answer

Loretto v. Teleprompter, 458 U.S. 419 (1982).

Nollan, 483 U.S. at $843-45$.

For a defense of that position, see Lee Anne Fennell, Hard Bargains and Real Steals:

Land Use Exactions Revisited, 86 IowA L.J. 1, 17-33 (2000).

483 U.S. at 831-32.

Id. at 837 (quoting J.E.D. Associates, Inc. v. Atkinson, 121 N.H. 581, 584 (1981)). 
that question. On the first point, Justice Brennan is clearly wrong to think that the possibility of a gainful bargain of a permit for the lateral easement justifies the government action. That argument will work in any case in which the net benefit to the landowner of getting the permit is positive, even if the government takes large chunks of the land for its own use. This rationalization of massive exactions fails to situate the so-called bargain in its larger context. Suppose that A steals a ring belonging to $\mathrm{B}$ that is worth $\$ 1,000$ and offers to sell it back to B for $\$ 500$. A prefers the money and B prefers the ring, so there will be a bargain with mutual gain. But the huge danger here is that this bargain incentivizes $A$ to take the ring in the first place, precisely so that he can sell it back to B, even if A only values the ring at $\$ 200$. In order to deter the original appropriation, the law must allow B to recover the ring without compensating A. Indeed, anyone would bridle at a bargain that allowed A to profit from taking the ring in the first place. All cases of ransom involve an initial taking, and one way to discourage these seizures is to prohibit the resale of the taken property and, by way of extension, to make it illegal to fence the goods to some third party. The entire situation is negative sum, and hence the Brennan mutual gain argument fails because it permits the government to profit from its uncompensated original taking, which required it to commit no resources at all.

The correct analysis therefore begins with the public choice conception that governments and voters will be more willing to acquire private property interests if they can obtain them at a price of zero. The Takings Clause therefore slows this situation down by forcing the purchase option to be exercised at market price. That risk of government faction is not limited to possessory interests. It also applies to the second form of servitudes, a restrictive covenant over land. Here too the government will haphazardly claim these intangible property rights if it can get for free what a private party would have to purchase. Hence there is no particular reason to allow regulations that restrict use to be imposed without compensation just because there is a good fit between what the state takes and what the public needs. Indeed, this is all the more reason to require payment and to let the state figure out the nexus question and the best disposition of public resources through the political process.

Once these fundamentals are established, it is possible to bring the monopoly analysis to its proper conclusion by noting the resource misallocations that follow from the exaction game, which apply across the board. There are two relevant comparisons. The first one, which is stressed in Nollan, is the relationship between the landowner's loss of the easement and his gain from the grant of the construction permit. The latter is greater than the former, so the easement is surrendered. The same would be done if the numbers came out the same way for restricting certain building configurations to preserve ocean views. But this is the wrong social comparison. The proper function of eminent domain is to permit transactions that use public coercion to get a net social gain, and to discourage the government from making those that do not. The just compensation requirement achieves that result. But if the government can grant permits bundled with easements, the rational calculus behind the just compensation requirement is circumvented. ${ }^{33}$ Under a just-

33 See generally Richard A. Epstein, The Bundling Problem in Takings Law: Where the Exaction Process Goes off the Rails, 4 Brigham-Kanner Property Rights Conf. J. 133 (2015). 
compensation regime, if the easement is worth more to the government than to the landowner, the taking that leaves both parties better off can be arranged (at some positive transaction cost). But if the easement is worth less to the government than it costs the landowner, the government will not go forward with the deal. This is the socially desirable result if the lateral easement costs the owner \$200 and generates only $\$ 100$ in social benefits. If bundling is allowed, however, all these deals go through regardless of relative values. As it costs the government nothing to grant or deny a permit, the state will use this bundling power to coerce transactions even where the landowner values the easement more than the public does (assuming that the permit is still more valuable than the easement). Only if the bundling is broken will a proper form of sorting take place because the public option is exercisable only at a fair market price. And while inefficient takings are still possible under a just compensation regime, the public financial consequences of these errors will ensure better visibility and accountability, which will incentivize community groups to develop better procedures to match the amount they pay in taxes with the benefits the public receives.

Unfortunately, Justice Scalia's discussion of both "out-and-out extortion" and the requirement of fit between the easement demanded and public purpose served direct the inquiry in the wrong direction. This permissive approach that allows governments to rationalize their way into takings is one of the reasons why the exaction game proliferates today. There is no limit of its use in regulatory takings cases, including those that require property owners to build new housing at their own expense when they evict tenants after lease expiration. ${ }^{34}$ The error that Scalia made from his narrow perspective generates huge negative consequences. In short, when governments can skirt the just compensation requirement by articulating a sufficiently clear nexus between the regulation and its public purpose, the Takings Clause offers little protection against coercion and inefficient transactions. So when the dust settles, Justice Brennan comes away with the lion's share of the practical gains. The social losses from the failure to unbundle the government's ability to issue permits from the government's obligation to pay actual compensation for takings are now a routine feature of modern takings law.

\section{Pennell v. City of San Jose.}

The second of Justice Scalia's opinions that I wish to address deals with the contentious issue of rent control, which has a long and sorry history in the United States Supreme Court. The issue first surfaces in Block v. Hirsh, ${ }^{35}$ in which Justice Holmes justifies the operation of the system in connection with the temporary, twoyear scheme put in place to deal with the run up in rental housing after the United States entered World War I. The justification proffered in Block was that the entire

$34 \quad$ San Remo Hotel v. San Francisco City \& Cty, 41 P.3d 87 (2002) (requiring landowners to build replacement housing for evicted tenants). This principle was expanded in California Building Industry Association v. City of San Jose, 61 Cal. 4th. 435 (2015) (imposing affordable housing mandates even if no housing was destroyed).

$35 \quad 256$ U.S. 135 (1921). 
scheme was legitimized by wartime emergency conditions. There was no inquiry into whether the occupation counted as a taking of private property, whether it was for public use, or whether just compensation was supplied. The next generation of rent control schemes had no emergency or time limitations, however, and the courts had to create other justifications.

Pennell ${ }^{36}$ involved a challenge to San Jose's rent-control system, an ordinance that claimed a very different set of government rationales:

These needs include but are not limited to the prevention of excessive and unreasonable rent increases, the alleviation of undue hardships upon individual tenants, and the assurance to landlords of a fair and reasonable return on the value of their property. ${ }^{37}$

The phrase "fair and reasonable return" is a strong signal that rental housing in San Jose was being treated as a public utility, a characterization which should be enough to condemn the rule to constitutional oblivion without further ado. The standard rationale for rate regulation is that the firm has a monopoly position as a common carrier or a public utility. Given the lack of market competition in such circumstances, the government may impose rate regulation that does not deprive the firm of a risk-adjusted competitive rate of return. Indeed the best recent opinion dealing with these issues was written by Chief Justice Rehnquist in Duquesne Light Co. $v$ Barasch, ${ }^{38}$ which developed the various approaches that could be adapted to set appropriate rates. ${ }^{39}$ But in a city-wide housing market there are no monopoly profits, and hence any rate regulation scheme necessarily reduces returns on the one side and increases costs on the other side, so that the return in question is necessarily less than the competitive rate. That is all that is needed to decide the case. All the particulars of a given rate-regulation scheme only explain the magnitude of the loss, which is not relevant given that none of these schemes contain any provision for the compensation of the aggrieved landlord.

Nonetheless, Rehnquist trots out the usual rational-basis review arguments, namely that rent control is justified under some standard of "consumer welfare," without once asking whether or not a system of price controls that favors sitting tenants could ever benefit the class of tenants as a whole. ${ }^{40}$ In addition to the complete exclusion of landlord welfare from this social calculus, this failure to consider that rent control systemically advantages current tenants over prospective tenants severely undercuts the consumer welfare justification. The superficial nature of the argument leads to an unfortunate situation in which all particular disputes are decided on collateral points that never arise under a correct initial analysis.

In Pennell, the question was whether a statutory "hardship to tenant" provision should allow the hearing officer to reduce the rents below those required under the fair rate of return formula. Clearly, if the statute is unconstitutional without this provision, its addition is not needed to make unconstitutional a provision that

\footnotetext{
485 U.S. 1 (1988).

San Jose Municipal Ordinance 19696, § 5701.2.

488 U. S. 299 (1989).

Id. at 316 ("The Constitution within broad limits leaves the States free to decide what ratesetting methodology best meets their needs in balancing the interests of the utility and the public.").

40 Pennell, 485 U.S. at 13.
} 
is already unconstitutional. But Rehnquist, ever the proceduralist, chooses not to reach that question. Even if the property owner has standing, the issue is not yet ripe because the particular provision has not been invoked in a concrete case. Pennell therefore lets an issue of major concern fester because it has yet to be applied, putting the problem off to a later day. But that patient approach seems unwise whenever there is a facial challenge to a particular provision that can be resolved without the collection of further facts in the specific case. This issue, for example, is quite different from a situation in which a court is asked to determine the proper scope of an injunction before the nature and source of the potential damage is established. There should be no question that a rent control statute that inevitably sets below-market rates will always run afoul of relevant legal principles regardless of case-specific facts.

To his great credit, Justice Scalia pushes the envelope in his concurrence and decides that ripeness claims notwithstanding, it is incumbent upon the court to look at this critical issue on its merits. At this point he concludes in a justly well-known passage that:

The traditional manner in which American government has met the problem of those who cannot pay reasonable prices for privately sold necessities - a problem caused by the society at large - has been the distribution to such persons of funds raised from the public at large through taxes, either in cash (welfare payments) or in goods (public housing, publicly subsidized housing, and food stamps). Unless we are to abandon the guiding principle of the Takings Clause that "public burdens ... should be borne by the public as a whole," this is the only manner that our Constitution permits. ${ }^{41}$

In essence, this powerful position claims that all subsidies to particular groups should come from general revenues, not from particular individuals. That claim was especially potent in Armstrong, the case cited by Justice Scalia, because the issue there involved materialmen's liens that had been placed on two United States Navy boats. The liens were imposed in the ordinary course of business because the general contractor had not paid the subcontractors for their work. In those cases, the general private-law rule is that any contractor has an action against the property on which the work was done, unless the owner has signed a lien waiver, which was not done in this case. Once the liens were imposed, however, the United States sailed the boats out of Maine waters, thereby dissolving the lien. The general proposition relied on in Pennell was that the private contractor in Armstrong should not be required to singlehandedly foot the bill for supplying public services to the United States. Rather than imposing its operating costs on individual citizens, the government must fulfill its obligations by drawing from general revenues.

In takings law, there is a powerful association between the exact language used in the case and the ultimate outcome. Whenever this Armstrong dictum is quoted,

41 Id. at 21-22 (internal citation omitted) (citing Armstrong v. United States, 364 U.S. 40, 49 (1960)). The full relevant passage from Armstrong reads: "The Fifth Amendment's guarantee that private property shall not be taken for a public use without just compensation was designed to bar Government from forcing some people alone to bear public burdens which, in all fairness and justice, should be borne by the public as a whole." 
full compensation is awarded and the costs of social programs are paid for from public revenues. Alternatively, compensation is almost never awarded in those cases where the compensation principle is framed in the weak language offered by Justice Brennan in Penn Central Transportation Co. v. City of New York:42

\begin{abstract}
The question of what constitutes a "taking" for purposes of the Fifth Amendment has proved to be a problem of considerable difficulty. While this Court has recognized that the "Fifth Amendment's guarantee . . . [is] designed to bar Government from forcing some people alone to bear public burdens which, in all fairness and justice, should be borne by the public as a whole," Armstrong v. United States, 364 U.S. 40, 49 (1960), this Court, quite simply, has been unable to develop any "set formula" for determining when "justice and fairness" require that economic injuries caused by public action be compensated by the government, rather than remain disproportionately concentrated on a few persons. ${ }^{43}$
\end{abstract}

At this point, Brennan concludes that the taking of air rights, a recognized property interest under New York State law, is not compensable because it is a mere restriction on use. Yet there is no explanation as to why the takings protection should apply more in one case than in the other, when the same public choice dynamics encourage the government, whether by dissolving a lien on a ship, imposing rent control laws, or enacting landmark preservation laws, to foist the costs of particular social programs on a small group of property owners. This discontinuity is apparent in Pennell's refusal to invalidate restrictions on private property that imposed public burdens on a narrow slice of the population. Justice Scalia's concurrence failed to understand the power of Armstrong's basic proposition. In so doing, he missed a golden opportunity to launch a broader attack on rent control by using the same public choice dynamic that condemns the hardship for tenant exception to condemn the rent control system as a whole.

The simple proposition is that the public, not the particular landlord, should be forced to bear the costs imposed by making housing available at below-market rents. The easiest way to achieve this end is for the state to offer tenants rent supplements to cover the difference between the market rate and the control price. These elements will have the added benefit of improving public deliberation, for now the public that wants to provide these benefits has to bear these costs. The net effect will be to reduce the frequency and extensiveness of programs as the price goes up.

Justice Scalia tries to wiggle out of this generalization, claiming, "[s]ingling out landlords to be the transferors may be within our traditional constitutional notions of fairness, because they can plausibly be regarded as the source or the beneficiary of the high-rent problem." 44 But the point is incoherent because landlords are not the source of the high-rent problem. Rather, it is the result of either shifts in supply or demand, or the imposition of some entry barrier, like zoning laws, that should be removed unless justified on health or safety grounds. And it is hard to conclusively say that landlords are the beneficiaries of "high rents" given that they take the full

\footnotetext{
438 U.S. 104 (1978).

Id. at $123-24$.

Pennell, 485 U.S. at 22.
} 
risk of falling rents. It would be equally ill-advised to say that current homeowners are the beneficiaries of high housing prices when they also bear the risk of falling prices. For all we know, property owners may have bought into the market at its peak. The general rule is that both landowners and landlords take the risk of a decline in price just as they might gain from an increase. A system of rent control that denies the upside while forcing the landlords to bear the downside hardly makes them beneficiaries.

In the end, Justice Scalia relies on an ad hoc distinction that makes no sense. The proper approach instead recognizes that any transfer of a term of years at belowmarket rents is a taking of a long-recognized and fully vested leasehold interest. But two obstacles prevented Justice Scalia from reaching that view. The first was his unwillingness to develop a systematic theory of property rights. The second was his view that judicial restraint requires only incremental adjustments to the law. His position here, as in Nollan, breaks new ground that only some other justices are prepared to follow. But his ad hoc approach also prevents the development of a fully articulated position, and in the end helps entrench the basic, but indefensible, rent control scheme.

\section{Lucas v. South Carolina Coastal Council}

\section{A. BACKGROUND}

The third of Justice Scalia's decisions that I shall critique, Lucas v. South Carolina Coastal Council, ${ }^{45}$ is also an exercise in missed opportunities. In this case, Justice Scalia again came out with the correct result, but again his flawed logic blocked the adoption of an intellectually coherent approach. The basic problem in the case was simple. The terrain of South Carolina's coastline on the Isle of Palm was, and is, intrinsically unstable in that the beach expanded and contracted in significant ways over relatively short periods of time. The expansions added to property, but the contractions threatened to knock individual structures into the ocean. Any party who bought beachfront property had to be aware of that risk, and thus had to calibrate his construction efforts to minimize the associated costs. Whether individual landowners used setbacks, sea walls, or stilts to keep the ocean at bay is a second-order question here, unlike in Stop The Beach Renourishment v. Florida. The correct design approach for a beachfront property owner is to adopt measures in keeping with the configuration, use, and value of his particular property, a decision that could be made separately by each individual landowner in deciding on whether or not to build.

Nonetheless, in 1988 the South Carolina legislature stepped in by passing the Beachfront Management $\mathrm{Act}^{46}$ that prohibited Lucas, like all other owners of vacant plots, from building anything at all on the two beachfront lots that he had purchased for $\$ 975,000$ prior to the enactment of the statute. Lower courts determined that the passage of the statute rendered both of these plots "valueless," so the question before the Supreme Court was whether this statute constituted a taking of the land. South Carolina's initial argument was that the development freeze in South

$45 \quad 505$ U.S. 1003 (1992).

46 S. C. Code Ann. § 48-39-250 et seq. (Supp. 1990). 
Carolina's beachfront statute did not work a taking of private property because the land remained in Lucas's hands. According to the state, the want of any physical occupation took the case out of the per se compensation rule for occupations that had been articulated in Loretto v. Teleprompter ${ }^{47}$ some years before. Instead, the government asserted that a regulatory prohibition on building was governed by the far laxer Penn Central ad hoc balancing test discussed above. ${ }^{48}$ Under that test, courts weigh the extent of the property deprivation against the state's interest, which in this case was the protection of the beach by creating a "buffer from high tides, storm surge [and] hurricanes." ${ }^{\prime 4}$

So here we have the basic counterpoint. On the one side is the explicit question of whether private property has been taken. On the other are questions over the scope of police power, whether the taking is justified as to its choice of ends, and whether the means chosen to reach those ends are also legitimate. Justice Scalia comes out with the right result that there is indeed a taking in this particular case. But like his earlier approaches in Nollan and Pennell, he sacrifices theoretical coherence in order to limit the scope of his opinion. Let us look at both sides of the issue.

\section{B. The Prima FaCIE TAKING}

The first side of the equation asks if private property has been taken, Justice Scalia's opinion in Lucas uses a process of imperfect analogical reasoning to get to what he regards as the ideal structure. But as with all cases of analogical reasoning, the process is only as good as the initial exemplar to which the comparison is made. In selecting a model for illustrating a prototypical taking, Scalia had a choice between two reference points on the opposite ends of the spectrum. The first of these is the Loretto decision, which limits the per se compensation rule to cases of physical occupation. The logical extension of that rule was good enough to cover the issue in Nollan, but it does not quite work in connection with the prohibition in Lucas, under which the property owner is indeed left in exclusive and undisturbed possession of the premises. Most objective observers would regard any total prohibition on all development of land as a big deal, tantamount to a taking. However, it may well be that leaving the property vacant does not leave it "valueless," as the trial court found, because even if the owner cannot build, he can still enter the land for other activities like sports and picnics, or sell it off to a neighbor for use as a side yard.

That riposte quickly leads to the next challenge. Suppose that the property owner has the absolute right to exclude all others from the land, but has no right to enter that land at all, for any purpose whatsoever, or to sell or lease it to anyone else. The Court's earlier decision in Kaiser Aetna v. United States ${ }^{50}$ stated that the "'right to exclude,' so universally held to be a fundamental element of the property right, falls within this category of interests that the Government cannot take without compensation." ${ }^{51}$ But just what happens if the right to exclude is protected while the

458 U.S. 419 (1982).

Penn Central, 438 U.S. at 1015-23.

Lucas, 505 U.S. at 1075 (Stevens, J. dissenting).

444 U.S. 164 (1979).

Id. at 179-180. The most famous defense of this position is found in Thomas W. Merrill, Property and the Right to Exclude, 77 NeB. L. REv. (1998). 
right to enter the property for any reason is removed? Clearly it takes a gutsy person to say that property right has not been taken, especially if the owner remains liable in tort for personal injuries caused by dangerous conditions on the premises, which he is not allowed to enter and correct. Something is deeply amiss with the entire enterprise of separating the fundamental property right to exclude from others in the bundle - like disposition, use and development — and then subsequently relegating the latter group to second-class status.

Yet that relegation is what Justice Scalia champions when he takes the view that Supreme Court precedent, starting with Pennsylvania Coal v. Mahon, ${ }^{52}$ holds that the Takings Clause reaches not only "direct appropriation[s]," but also covers some regulations as well. ${ }^{53}$ But which ones? In Mahon, Justice Holmes insisted that protection against takings only covered those regulations that went "too far," 54 without ever once explaining why some unspecified difference in degree flipped the liability switch from the on to the off position..$^{55}$ This amorphous sliding scale mechanism which sometimes finds a taking, and sometimes does not, is the worst possible way to model discontinuities. Instead, the correct approach in all cases has two steps. First, the preliminary takings inquiry simply asks the yes/no question of whether the government has restricted the exercise of a private property right. If yes, there is a taking. Only then does the aforementioned question of regulation severity become relevant in determining the level of compensation required under a maxim that states, "The more you take, the more you pay." Under this model, differences in degree cleanly correspond to the amount of compensation owed, a result that can only be reached by jettisoning the view that there is any categorical distinction between regulations and takings. Small differences in how the government frames an intrusion on private property (i.e., as a regulation or as an invasive taking) should not produce huge differences in outcome. Instead, the on-off switch for whether a taking has occurred should correspond to other bright-line rules that govern social conduct, such as boundary lines for land, road dividers for highways, and fair and foul lines for sports contests. Exceptions only come up in rare cases, usually after one party has deviated from the rules, say by forcing another over a boundary line. Thus the doctrine of last clear chance in torts, for example, requires adaptations made in good faith when one party knows that the other party has already deviated from the rules of the road, and in this instance the party that has to make the adjustments is uniformly protected by some form of a good faith rule. ${ }^{56}$ Just as other areas of law prefer bright-line rules with narrow categorical exceptions, so should takings law eliminate the ambiguous sliding-scale analysis for determining at what point a regulation is severe enough to constitute a compensable taking.

Nonetheless, Justice Scalia tries to avoid this conceptual objection by placing the tipping point so that the imposed regulation becomes compensable whenever there is a "deprivation of all economically feasible use" of the property taken. ${ }^{57}$ Again, his Lucas opinion offers no acceptable explanation for this discontinuity.

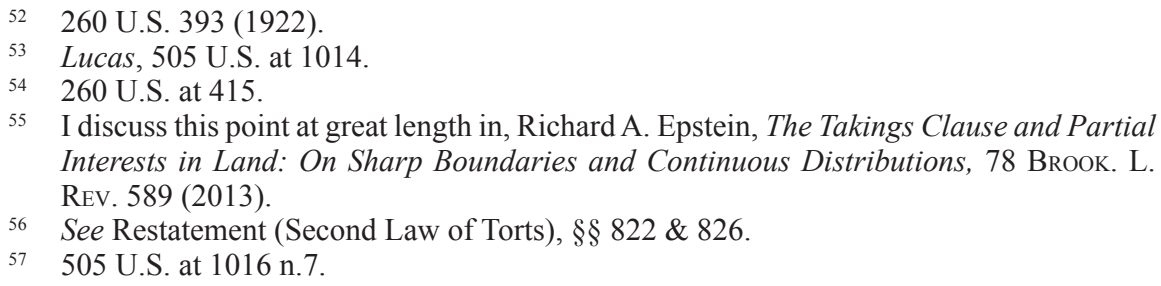


At one point he claims that this "total deprivation of beneficial use is, from the landowner's point of view, the equivalent of a physical appropriation." ${ }^{58}$ But by the same token he never explains why a partial deprivation of economic value is not equivalent to a partial physical appropriation that would be compensable under the Loretto rule. Instead, he adds an apologetic footnote, beginning with the word "regrettably," that only sows further confusion on the area. ${ }^{59}$

The key problem here is the oft-discussed "denominator question" that poses this brain teaser: what happens when the government requires a landowner to leave 90 percent of land in its natural state in order to receive permission to develop the other 10 percent? One way to look at this is as a 100 percent loss of use of 90 percent of the land, at which point full compensation is owed for the associated loss in value. But the alternative is to look at it as a partial taking of the entire plot of land - that is, a 90 percent loss of use for the whole parcel - a partial devaluation for which the Penn Central test could well deny any compensation due to the retained use of the 10 percent. Whether that tipping point is at 90 percent, 80 percent, or elsewhere is still, after nearly 40 years of litigation, anybody's guess.

The only reason this impasse arises is because Justice Scalia buys into the flawed Penn Central paradigm. He thinks that the issue is the ratio of the value retained to the overall value. The correct approach, however, is to order compensation for the amount of the property taken, regardless of the fraction left behind. This straightforward before-and-after comparison makes the choice between physical and regulatory takings irrelevant. If the value of a $\$ 100,000$ plot of land is reduced to $\$ 20,000$ when construction is blocked on 90 percent of the property, $\$ 80,000$ is owed either way. Nor is it possible to attack this approach as a devious form of "conceptual severance," which Professor Margaret Radin insisted is a dangerous ploy intended to subvert the Penn Central rule by letting property owners divide their land into small chunks so that the numerator occupies a fraction of the (shrunken) denominator. ${ }^{60}$ But there is no need to engage in any such artifice if the analytical framework asks the right question: how much property has been taken? What is utterly irrelevant in all cases is the amount of property left in the hands of the owner, or the ratio between the property taken and the property left behind.

In principle, it is impossible to devise the correct approach to the takings issue so long as the empty distinction between physical takings and regulatory takings remains doctrinally dominant. The point is evident enough from the landmark regime imposed in Penn Central, where the loss of air rights could be regarded as the partial taking of the fee simple or the entire taking of the air rights. Justice Brennan's entire apparatus of regulatory takings, uncritically accepted by Justice Scalia, goes astray by insisting that the existence of a compensable taking depends on the ratio of the particular incident taken to the value of the parcel as a whole. ${ }^{61}$

\footnotetext{
Id. at 1017 .

59 Id. at 1016 n.7 ("[T] use' rule is greater than its precision, since the rule does not make clear the "property interest' against which the loss of value is to be measured.").

60 Margaret Jane Radin, The Liberal Conception of Property: Cross Currents in the Jurisprudence of Takings, 88 CoLum L. Rev. 1667 (1988).

${ }^{61}$ Penn Central, 438 U.S. at 130-31 ("In deciding whether a particular governmental action has effected a taking, this Court focuses rather both on the character of the action and on the nature and extent of the interference with rights in the parcel as a wholehere, the city tax block designated as the "landmark site.'”).
} 
The situation does not get any easier in a world of regulatory takings if the Court is asked to distinguish between two different hypothetical regulations. The first does not allow the state to use the air rights, but only to block the owner's use of them. The second lets the state develop those air rights or sell them to someone else. Under the Penn Central approach, only the second action is certainly compensable, despite the fact that both regulations equally impair the owner's property rights. The correct reformulation of this analysis is therefore a rule which always requires some compensation under a standard stating that "The more you take the more you pay," so that all the nuances come out on the valuation question, not the threshold compensability question. This approach is perfectly universal whether the case involves air rights, mineral rights, liens, or covenants. That formulation also should always take into account any "severance damages" to any portion of property retained, just as it should take into account any added value to the property that the owner retained..$^{62}$ Only this approach is sufficient to eliminate the risk of strategic government behavior, for otherwise the state will be tempted to first regulate without compensation and then later acquire outright possession and ownership of the now-useless property at bargain prices. The correct rule requires compensation for the loss in value each step of the way.

That uniform approach is exactly how it should be, because the twin fundamental concerns in takings cases - fairness to the landowner, and constraints on government rent-seeking behavior-loom every bit as large with a zoning or a landmark preservation scheme as they do with the direct occupation of property. Indeed, given the potentially greater reach of land use regulations, the dangers of unfairness or strategic behavior are greater with widespread but slanted regulation than with isolated occupation cases. In all cases, there is no need to guess in advance which of these schemes is likely to prove more successful than others. ${ }^{63}$ It is quite enough to wait for the outcome of events like the taking in Lucas before making the decision.

Indeed, Lucas offers an instructive explanation of how matters can go awry. Once the Supreme Court held that the South Carolina beachfront law worked a taking, the trial judge forced the state to take title to the property by paying Lucas its full market value. Naturally, the state had set aside no budget for that expenditure, so it sold the land to two new owners for full market value, and these new owners in turn built their own oceanfront homes. ${ }^{64}$ Incentives matter.

\section{Police Power Justifications}

Justice Scalia is every bit as confused in Lucas when dealing with the question of whether there was any police power justification for taking the property. As noted above, the centrality of nuisance in the police power literature rests on the simple

62 For the complications, see United States v. Miller, 317 U.S. 369 (1943).

${ }_{63}$ For one articulation of that political process claim, see Saul Levmore, Takings, Torts, and Special Interests, 77 VA. L. Rev. 1333, 1344-45 (1991). For my response, see Richard A. Epstein, The Unfinished Business of Horne v. United States Department of Agriculture, 11 N.Y.U. J. LAW \& LiBERTY 734 (2016).

64 Oliver A. Houck, More Unfinished Stories: Lucas, Atlanta Coalition, and Palila/Sweet Home, 75 Colo. L. Rev. 331, 366 (2004): "In November 1993, Lucas's oceanfront lots went at auction for $\$ 730,000$.” 
proposition that the state is allowed to act as the agent of the public at large in responding to threats that neighbors impose. If private actors do not have a valid cause of action against their neighbor, then the government, as their agent, cannot rise above their position by claiming some novel set of rights. If that is allowed, then all interest groups will seek to remove cases from the tort system into the administrative process. Instead, just as the private neighbor must purchase relief if it wants to secure additional rights that are not protected by the law of nuisance, the government cannot expand the police power to avoid the compensation requirement of the Takings Clause. ${ }^{65}$ Thus it will not do to say that the beautification of the general region offers a police power justification for prohibiting all construction on the site. The desire to enhance the open spaces along the beach surely counts as a valid public use, which, unlike the exercise of the police power, always requires the payment of compensation.

This key distinction inevitably gives rise to some complex marginal cases, but the basic lines of nuisance law are clear in two key respects: First, no one person has the right to a view over the land of a neighbor, and no one can acquire that right by building first. Otherwise, there is a senseless race to early development in which everyone is a loser. Second, competition from a nearby business does not constitute a nuisance. Instead, the nuisance law hones in on pollutants, noises, vibrations, odors and similar invasions. There is an inveterate tendency, even among private law scholars, to claim that the principles of nuisance law are muddy and indeterminate, ${ }^{66}$ but it is critical not to be distracted by a set of marginal examples in an area whose principles are capable of coherent and rational development. ${ }^{67}$

Given this principled view of nuisance and the police power, it is very clear that the state cannot come up with any rationale that would justify preventing the reconstruction of new buildings on land, especially when the proposed structures are in keeping with those already there. Beautification may well be a good reason to impose restrictions on land, but if so, such restrictions take an interest in private property for public use and thus require compensation. It could also be argued that perhaps a total end to construction is needed to prevent injury to someone caught on the beach during the storm, but that wildly improbable consequence does not justify blocking construction on the beach, or indeed anywhere else. Perhaps some building safety requirements may be imposed, but these are surely less restrictive than an outright ban on construction. In effect, the police power system requires a two-stage analysis, one dealing with ends and the other with means. The class of ends can be rigorously defined, and beautification is not among them. The potential for future harm is far more difficult to pinpoint but here, as with private remedies, the correct approach is to make some good faith effort to minimize the sum of two errorsblocking projects that should be allowed to go forward, and permitting projects that

65 For a fuller articulation of these principles, see Richard A. Epstein, Nuisance Law: Corrective Justice and its Utilitarian Constraints, 8 J. Legal STud. 49 (1979).

66 See the sources cited by Justice Blackmun in Lucas, 505 U.S. at 1055 n.19 (Blackmun, J. dissenting) ("There is perhaps no more impenetrable jungle in the entire law than that which surrounds the word 'nuisance.' It has meant all things to all people, and has been applied indiscriminately to everything from an alarming advertisement to a cockroach baked in a pie.") (quoting W. Keeton, D. Dobbs, R. Keeton \& D. Owen, Prosser AND Keeton on The LaW of Torts § 616 (5th ed. 1984)).

67 For historical context, see Joel Brenner, Nuisance Law and the Industrial Revolution 3 J. Legal Stud. 403 (1974). 
should be blocked due to legitimate public safety concerns. This particular case is one where the balance of possible errors heavily favors the landowner.

Nonetheless Justice Scalia manages to confuse this position in an untoward burst of linguistic skepticism, asserting:

[T]he distinction between "harm preventing" and "benefit-conferring" regulation is often in the eye of the beholder. It is quite possible, for example, to describe in either fashion the ecological, economic, and esthetic concerns that inspired the South Carolina Legislature in the present case. One could say that imposing a servitude on Lucas's land is necessary in order to prevent his use of it from "harming" South Carolina's ecological resources; or, instead, in order to achieve the "benefits" of an ecological preserve. ${ }^{68}$

Pure doubletalk. If Justice Scalia actually meant what he said about collapsing the longstanding distinction between harms and benefits, he would rob takings law of any and all coherence. His extreme form of linguistic skepticism seriously compromises the rule of law by making every case indeterminate. Thus when I do not hit you, I have conferred on you a benefit. When I have not given you a handout, I have inflicted a harm. When I do nothing to you either way, I have both harmed and helped you at the same time. The only way to avoid these absurdities is to look back to the common law rules that link harm to the infliction of a nuisance, and benefit-conferring relationships to those which support an action for restitution, as when I rescue your animals from danger when you are not in a position to do so.

In the end, Justice Scalia reluctantly, but inconclusively, makes his way back to the standard usages when he reverts to the Restatement provision defining public and private nuisances ${ }^{69}$ but not before he cites a large number of legal sources that proclaim the incoherence in the law of nuisance due to the difficulties associated with making coherent causal judgments. Thus at one point, he quotes from a wellknown article by the late Professor Joseph Sax to the effect that "[T]he problem [in this area] is not one of noxiousness or harm-creating activity at all; rather it is a problem of inconsistency between perfectly innocent and independently desirable uses." ${ }^{" 70}$ Note that under this test, both the private and the public law of nuisance falls to pieces, because any case can come out any way. That result is not possible with the traditional view that stresses the nontrespassory nature of the invasion as the heart of the tort. ${ }^{71}$ In dealing with this issue, H.L.A. Hart and Tony Honore hit the nail on the head when they attack this view by saying:

It is fatally easy and has become increasingly common to make the transition from the exhilarating discovery that complex words like "cause" cannot be

\footnotetext{
Lucas, 505 U.S. at 1024.

$I d$. at 1025 (citing Restatement (Second) Torts, § 821B, 822).

70 Id. (citing Sax, Takings and the Police Power, 74 Y ALE L. J. 36, 49 (1964) (alterations in original).

71 Morgan v. High Penn Oil Co., 77 S.E.2d 682, 689 (N.C. 1953): "[T]he feature which gives unity to this field of tort liability is the interest invaded, namely, the interest in the use and enjoyment of land; that any substantial nontrespassory invasion of another's interest in the private use and enjoyment of land by any type of liability forming conduct is a private nuisance".
} 
simply defined and have no "one true meaning" to the mistaken conclusion that they have no meaning worth bothering about at all, but are used as a mere disguise for arbitrary decision or judicial policy. This is a blinding error, and legal reasoning will never be understood while it persists. ${ }^{72}$

Scalia falls into just this hyperrealist trap, so that his Lucas decision is infected with an acute dose of legal realism that makes it impossible for him to see clearly through the fog. Even though he comes out the right way in this case, his opinion articulates no clear principle that allows him to deal with the next case. Thus the extent of the government's ability to invoke the police power in controlling nuisance remains wholly unclear, as does the takings rule for cases in which the government restriction on land use is at most partial. Finally, there is no guidance for cases when the scope of the initial restriction may be overbroad, and is therefore amenable to being cut down to avoid a takings challenge.

These intellectual confusions come at a very high price. For example, the elastic definition of harm allows governments to obtain large swathes of land for nature preserves without compensation: after all, preservation of any site is arguably necessary to prevent injury to animal or plant life. Yet what is missing in this broad definition of harm is any notion of externalization that one person's actions inflict on the person or property of another. In those cases, where one person degrades one portion of his own land in order to benefit another, he bears the full cost of his own losses, and thus is far less willing to harm his own property than someone else's, which is why the tort law is imposed for harms on strangers but never for self-inflicted losses.

Ideally, therefore, these habitat conservation cases should always come out in the opposite direction under a rule that requires the government to pay for such restrictions. Under the current regime, however, landowners know that the government can swoop in at any moment and freeze land development due to environmental concerns. This fear of future, uncompensated restrictions creates a powerful incentive for individuals to proactively destroy habitat so that the government cannot later assert an interest in preserving this habitat. ${ }^{73}$ The current system also makes it all too easy for the government to, at no cost to itself, designate certain land as protected habitat, and then issue a building permit only if the landowner agrees to "mitigate" the damage by purchasing other land for government use at his own expense to cure the supposed loss. ${ }^{74}$ There is of course no requirement that the harm identified by the government threaten the land of others, as is required as part of a nuisance remedy in classical tort law. Indeed, this tactic of extracting concessions by withholding private development rights is yet

\footnotetext{
H.L.A. Hart \& A.M. Honoré, Causation In the LaW 3 (1959).

73 The wrong result on this issue was reached by the Supreme Court in Babbitt v. Sweet Home Chapter of Communities for a Great Oregon, 515 U.S. 687 (1995). Justice Scalia offered a technical dissent on the basis statutory language, $i d$. at 714 , which nowhere addressed any of the incentive questions raised by the case. For my views, see Richard A. Epstein, Babbitt v. Sweet Home Chapters of Oregon: The Law and Economics of Habitat Preservation, 5 Supreme Court EConomic Review 1 (1996).

74 For an illustration of this process, see Koontz v. St. Johns River Water Management Dist. $133 \mathrm{~S}$. Ct. 2586 (2013). It is perfectly correct to insist that nuisances be mitigated. But it is wholly incorrect to insist that ordinary development be mitigated when there is no nuisance to control.
} 
another version of the Nollan bundling mistake discussed above. ${ }^{75}$ In the end, Lucas carves out a narrow island in which compensation is required, but in effect expands the scope of government control by blessing regulation without compensation for virtually any partial taking of land, even in those cases where there are no common law nuisances involved. With the decision in place, the scope of government overreach only increases.

This point, moreover, has not been lost on defenders of the modern progressive state. In writing about these issues in a memorial tribute to Justice Scalia, Professor Cass Sunstein offers high praise for how the Lucas decision raised the full range of issues needed to undertake the "total taking" inquiry. He cites the passage from Justice Scalia's Lucas opinion that relies on Penn Central to observe that the relevant factors include

among other things, the degree of harm to public lands and resources, or adjacent private property, posed by the claimant's proposed activities, the social value of the claimant's activities and their suitability to the locality in question, and the relative ease with which the alleged harm can be avoided through measures taken by the claimant and the government (or adjacent private landowners) alike. ${ }^{76}$

Given this laundry list of factors, it is easy for Sunstein to announce happily that "Lucas is an excellent illustration of living constitutionalism." 77 Unfortunately, his observation is all too true. By relying on a random set of relevant factors of indeterminate importance, the test permits any result in any case for any reason at any time. Such an approach guarantees that Lucas will be a one-hit wonder, which is what actually happened in the case. Knowing full well that the total taking approach would put it at major financial risk, South Carolina amended its Beachfront Management Act to authorize the Coastal Council to issue "special permits" in select circumstances that would allow for the construction of new units, or the reconstruction of old ones, on the seaward side of the statutory baseline. ${ }^{78}$ Justice Scalia refused to allow the subsequent passage of this statute to deter his constitutional review. But his victory was for one case and one case only. ${ }^{79}$ Going forward, every legislature everywhere will follow the South Carolina example by integrating safety valves into construction bans in order to escape the per se Lucas rule. But by design the concessions will be minor, and the burdens of proof heavy, with only the hardiest of souls making their way through the regulatory maze. The key point is that the "total taking" rule expounded in Lucas allows states to easily skirt the principle by purportedly leaving something to landowners, thus removing cases from the total taking approach in Lucas and putting the entire field of land use regulation back into the rational basis world of Penn Central. No wonder Sunstein admires the Lucas opinion. Its calculated prolixity makes the constitutional protection of property rights stillborn the day that Lucas was decided.

\footnotetext{
See supra note 30 and accompanying text.

76 Lucas, 505 U.S. at 1030-1031 (internal citations omitted), quoted in Cass Sunstein, In Memoriam: Justice Antonin Scalia, 130 Harv. L. Rev. 22, 25 (2016).

77 Sunstein, at 26.

78 S. C. Code Ann. § 48-39-290(D)(1) (Supp. 1991).

79 Lucas, 505 U.S. at 1010-1014.
} 


\section{Stop the Beach Renourishment}

The last of the cases, Stop the Beach Renourishment, ${ }^{80}$ involves a form of environmental regulation that should be praised for its sophistication. Justice Scalia rightly upholds the Florida system, but again does so for reasons that reveal a fundamental misunderstanding of the entire logic of environmental protection. At issue in Stop the Beach was the constitutionality of Florida's Beach and Shore Preservation Act ${ }^{81}$ which set out an elaborate procedure whereby government intervention could be used to protect valuable beachfront property from erosion.

The problem here is a ticklish one because the protection of beachfront property normally involves the creation of a seawall. In principle, each beachfront owner could erect an individual wall to protect his own land, but this would be ineffective. Beachfront lots tend to be narrow so as to maximize the number of property owners that have direct access to the beach. Consequently, individual walls are both expensive and ineffective against surging storm waters that will simply flow around their ends. Yet at the same time, it is difficult to secure voluntary cooperation among neighbors to build a common wall that could do the job at lower cost with greater effectiveness. There is, in other words, the classic collective action problem to which well-focused government intervention could supply a solution. ${ }^{82}$

In this case, the statutory scheme contained these key elements. First, the wall was to be erected along an "erosion control line" ${ }^{83}$ where it provided the best level of protection. Second, the public gained an easement of access over the private land that lay to the seaward side of the wall. Third, the owners of the beachfront properties retained their view rights. The wall did not prevent owners from reaching the beach, and the government could not build any structure on the beach that blocked the view from the properties.

In an attempt to stop this plan, the private owners claimed a taking of "(1) the right to receive accretions to their property; and (2) the right to have the contact of their property with the water remain intact." ${ }^{\prime 4}$ The former "accretions" claim refers to the common law rule whereby slow additions and losses to beachfront property belong to the landowner. In this case, the landowners would no longer receive these accretions because additions at the water's edge would now accrue to the state. The second claim refers to the fact that the wall necessarily impaired unlimited access to the beach.

The proper response to these claims is one that first admits both charges as true, but then demonstrates that the property owner has received in-kind compensation for the restrictions in question. That in-kind compensation refers to the package of benefits generated by the wall, including the protection against the loss of further land by erosion and the preservation of view and beach-access rights. If the value of these equals or exceeds the losses in question, the prima facie taking is compensated and no additional compensation is necessary. In this case, in-kind compensation is presumed, as the wall confers a significant benefit by solving the

560 U.S. $702(2010)$.

1961 Fla. Laws ch. 61-246, as amended, Fla. Stat. $\S 161.011-161.45$ (2007).

See Mancur Olson, The Logic of Collective Action (1965).

Stop the Beach, 560 U.S. at 710.

Id. at 711 . 
collective action problem faced in organizing the response needed to stop erosion. A more fine-grained inquiry could ask whether the scheme has provided full or only partial compensation to each beachfront owner, which could be answered by comparing the fair market value of the properties before and after the scheme is put into place. As a first approximation it looks as though all the landowners are in about the same position, so that in general it is best to use the average benefit to assess individual cases. A different procedure would be required if individual owners were so uniquely situated that some derived little benefit from the wall-for example if one of the affected properties sat on a rocky outcrop that was immune to flooding. In the instant case, however, there is no suggestion that any of the landowners did not benefit from wall's protection, so solving the heterogeneity problem could wait until another day.

In dealing with this statutory scheme, Justice Scalia does not mention the just compensation side of the equation, but contents himself with asking whether a taking has taken place. He then veers into a discussion of whether judicial takings of private property should be compensated, to which he gives the sensible answer that the prohibition against takings applies as much to the judicial as the legislative branch of government. ${ }^{85}$ That question is raised because the decision of the Florida Supreme Court below denied that property owners had either the right to accretions or the right to have littoral (i.e. beachfront) land remain in contact with the water. In dealing with this issue, Justice Scalia followed prior Florida case law, most notably Martin v. Busch, ${ }^{86}$ which took the view that once the state drained water from a lake, it continued to retain ownership of the land that had been previously below the mean-high water line.$^{87}$ That point may be true enough, but it hardly follows from Martin that the former lakefront owner should not recover compensation for his loss of access rights to the lake. As a general matter of water law, the ultimate sin is the diversion of water from its proper channel. That action is usually subject to an injunction when done by a private party, and so it follows that the state's exercise of eminent domain for the same purpose carries with it an obligation to compensate for the loss of access rights.

Nonetheless, Justice Scalia finds that the state is entitled to drain those lands because it is permissible for Florida courts to treat "state-created avulsions" in the same fashion as natural ones. It is at just this point that the opinion goes off the rails. The notion of avulsion is used in opposition to the notion of a gradual change by alluvion. ${ }^{88}$ In the latter case, a gradual movement of a boundary line induced by water movement does not result in any change in ownership. Under long established legal principles, the riparian or littoral owner continues to own the land ${ }^{89}$ Any other rule would create tiny useless slivers of shorefront land that could be reduced to ownership by the first occupier, thereby blocking the primary landholder's much-needed access to the water. But by the same token, an avulsion, or a violent shift in the location of land brought on by natural forces, requires a very different solution. Under the natural law (where there is no state at all), land that

\footnotetext{
Id. at $713-14$.

112 So. 274 (Fla. 1927).

Id. at 287.

For a discussion of these points, see Nebraska v. Iowa, 143 U.S. 359 (1892).

For an early discussion, see Justinian, Institutes Book II, Title I, §§ 20-22; Gaius Institutes, Book II 70-72; William Blackstone, Commentaries on the LaWs of England ch. 16 (1766).
} 
had been formerly occupied by the water was now divided between its two former riparian owners, usually by a thread down the middle of the river. It is only after the formation of government that the state can claim ownership of the lakebed..$^{90}$ And at the new location of the waterway, a system of riparian rights was installed in the same manner that was used at the original watercourse. However, these rules for avulsions have one important caveat: sudden changes in waterways never refer to changes wrought by private individuals. For example, a landowner could not invoke the law of avulsion and obtain full title to a river by damming up its natural course and redirecting it to his own land. ${ }^{91}$

The rules for government action are no different. If the state diverts water from a river for its own use, it has to compensate the downstream riparian or littoral owners for the loss of their water rights. Any state court that held that the state was entitled to divert water into its own reservoir would surely commit a judicial taking. The only real question in these cases is whether the state is entitled, even with compensation, to make the appropriate diversion. ${ }^{92}$ Avulsions are only acts of God. It makes no more sense to speak of a man-made diversion as an act of God than it does to speak of arson as an act of God. Justice Scalia thus hopelessly confuses the common law categories. Yet once this confusion is made, the case becomes simple, at least for Justice Scalia. Since there was no antecedent property right at common law, there is no place for protecting either riparian or littoral owners under the Takings Clause.

The result under Florida law may seem counter-intuitive. After all, the landowners' property has been deprived of its character (and value) as oceanfront property by the State's artificial creation of an avulsion (i.e. the wall and easement that cuts off waterfront access). Perhaps state-created avulsions ought to be treated differently from other avulsions insofar as the property right to accretion is concerned. But nothing in prior Florida law makes such a distinction, and Martin suggests, if it does not indeed hold, the contrary. ${ }^{93}$

Under Justice Scalia's analysis, the outcome of Stop The Beach therefore does not change even if one removes the key features that made it a sensible statute: the protection of the land and the preservation of access and view. Indeed, under the majority's rule that simply permits the state to claim title to avulsions, it would be possible to cut off access to lakes and rivers under all circumstances without giving nearby landowners a dime in compensation. Or the state could build on that newly acquired strip of land a massive structure that blocked the former owner's view. The entire body of water law is a delicate interplay that is designed to protect against those extreme results. It would be a great tragedy to allow the misguided notion of an artificial, state-created avulsion to upend several thousand years of water law. But just this result is reached due to the Court's unwillingness to fully analyze the Takings Clause.

90 Blackstone, Commentaries on the Laws of England ch. 16. "But, if the alluvion or dereliction be sudden and considerable, in this case it belongs to the king: for, as the king is lord of the sea, and so owner of the soil while it is covered with water, it is but reasonable he should have the soil, when the water has left it dry."

91 See, e.g., Stratton v. Mountain Hermon Boys School, 103 N.E. 87 (Mass. 1913).

92 See, e.g., Adams v. Greenwich Water Co., 83 A.2d 177, 179 (Conn. 1951), involving an "action to enjoin the defendant [water company] from diverting and from attempting to take by condemnation, any of the waters of [the Mianus River]."

93 Stop The Beach, 560 U.S. at 730-31. 


\section{CONCLUSION}

The central message of this paper is that constitutional interpretation is an impossible task absent a mastery of the private law concepts on which the Constitution relies. This proposition is of vital importance for anyone who wants to give a coherent account of how the Constitution protects private property-the most central concept of private law around which all else is organized. That last notion has a long and complex history as it applies to both land and water. For the most part, the longstanding private law systems governing these questions have worked out ingenious accommodations to competing claims over private resources.

This set of understandings is necessarily brought over into public law whenever the state seeks to act in ways that disadvantage private landowners. In some cases, these government actions are fully justified. In other cases, they are fully compensated. But in many cases neither is true. A faithful application of the Takings Clause seeks to draw boundary lines on property regulation and acquisition, which it can only do if it fully grasps how the principles of limited government apply in this context. No government can simply "redefine" rights in a manner that justifies its action. Instead when it acts, it must do so as the agent for all or part of the public. Where private parties can enjoin the action of their neighbors without compensation, the government actor can do the same, but subject to the same limitations on injunctive relief. And where the government takes or regulates land for public use, it must offer compensation - monetary or in-kind - to the private owner. In all of these cases, Justice Scalia was never able to articulate or apply the central propositions of takings law in a comprehensive and orderly fashion, and thus his decisions have an erratic quality even when, by the introduction of offsetting errors, they reach the correct result in individual cases. And that difference surely matters. Get the right logic in Nollan, and it becomes possible to develop a coherent approach to exactions that covers both physical and regulatory takings. Get the right logic in Pennell, and it is possible to root out the rent control laws and their systematic deleterious effects on residential rental housing. Get the right result in Lucas by the right logic, and the constitutional oversight over abusive land-use regulation is avoided. Get the right logic in Stop the Beach, and dangerous environmental overreach can be thwarted. In each of these cases, the deficiencies in Justice Scalia's opinions have nothing to do with the grand and recurring disputes over the relationship between textualism and originalism. Rather, they concern the technical program of constitutional interpretation that easily goes astray. But lest one be too hard on him, none of his colleagues on the bench have been able to develop a coherent view of this field either, which will continue to limp along, case by case, unless and until the Court articulates and applies the systematic principles that underlie this field. 